\title{
Analysis of the Village Fund Utilization for Poverty Alleviation
}

\author{
${ }^{1}$ Rene Iwo Pearce \\ ${ }^{1}$ The Department of Sociology, University of North Carolina at Chapel Hill, NC, United States. \\ ${ }^{1}$ riwop@unc.edu
}

\author{
Article Info \\ Journal of Journal of Enterprise and Business Intelligence (http://anapub.co.ke/journals/jebi/jebi.html) \\ Doi: https://doi.org/10.53759/5181/JEBI202101004 \\ Received 20 August 2020; Revised form 12 September 2020; Accepted 12 December 2020. \\ Available online 05 January 2021. \\ (C2021 Published by AnaPub Publications.
}

\begin{abstract}
This study aims to describe and analyze the use of village funds in poverty alleviation and the factors that influence the use of village funds sourced from the State Budget for poverty alleviation. The research used the case study method. The results showed that the utilization of village fund had been implemented in accordance with the Regent Regulation No. 6 of 2019 concerning technical instructions and procedures for the distribution and determination of details of village fund given to 142 villages in 13 subdistricts, allocated equally and fairly based on the basic allocation, affirmation allocation, and formula allocation calculated by taking into account the number of villagers, the village poverty rate, the area of the village and the level of geographical difficulty. In terms of utilization of village fund through a mechanism agreed upon in the village deliberations as the highest village forum involving village government officials, the Village Consultative Body, and elements of the village community, the use, and utilization of village fund which increase every year are more prioritized in Physical Village development $(95.28 \%)$ of the total village fund, compared to the use of village fund for community development and empowerment activities (4.72\%) for poverty reduction, and the use of village fund has not significantly reduced poverty rates in rural areas. Factors that influence the use of village funds are (1) conflicting regulations on the use of village funds, (2) weak supervision from both government officials and the community, (3) the low commitment of village elites in utilizing village funds to reduce poverty rates in rural areas.
\end{abstract}

Keywords - Village Fund; Poverty Alleviation; Village autonomy.

\section{INTRODUCTION}

Village autonomy is the right, authority, and obligation to regulate and manage government affairs and community interests, based on the rights of origin and socio-cultural values that exist in the community to grow and develop following the development of the village. In exercising rights, authority, and freedom in implementing village autonomy must uphold the values of responsibility towards the Unitary State of the Republic of Indonesia by emphasizing that the village is an inseparable part of the Indonesian nation and state. The exercise of the rights, powers, and freedoms of village autonomy demands responsibility for maintaining integrity, unity in the Unitary State of the Republic of Indonesia, and the responsibility to realize the welfare of the people implemented in accordance with the corridor of prevailing laws and regulations.

The village is a government organization that politically has certain authority to manage and regulate its citizens or communities. With this position, the village has a very important role in supporting the success of governance and national development at large. The village is at the forefront of achieving the success of all government affairs and programs. Therefore, the government provides a large Village Fund incentive to villages as the government structure closest to the community for improving social services and poverty reduction [1], encourage income [2], reducing resource conflict [3], and strengthening institutional supports [4].

The use of village funds is based on general guidelines for determining priorities for the use of village funds. Based on the Regulation of Ministry of Villages, Development of Disadvantaged Regions, and Transmigration of the Republic of Indonesia Number 22 of 2016 concerning Determination of Priorities for the Use of the Village Fund in 2017 as a guideline for the provincial government, district/city government, and village to manage priority setting for the use of Village fund based on democratic village governance and social justice [5].

The regulations regarding the procedures for the distribution and determination of details of Village fund for each Village in Wajo District have been contained in the technical instruction for the use of Village fund, based on the Wajo Regent Regulation No. 3 of 2017. With this technical instruction, the Village Government is required to manage the Village fund effectively and accountably. Effective is the extent to which the target (quantity, quality, and time) has been achieved by the Village government in the use of Village fund. While the accountable is is the level of transparency of success or failure that has been achieved by the Village government in the use of the Village fund. 
The important thing that can be applied in managing the Village Fund by involving the community is the need to carry out activities with a self-management pattern, using local labor, and utilizing local raw materials in the village. The self-management pattern means trying to plan and implement these activities independently by the village so that the money used for the development will not flow out of the village. By using local manpower, it is hoped that the implementation of these activities can absorb labor and provide income for those who work. Meanwhile, the use of local raw materials is expected to provide income to the people who have these raw materials and creating perfect market mechanisms [6], [7].

The Village Fund that revolves in Wajo District in 2019 is Rp. 119,030,097,000 (one hundred and nineteen billion, thirty million, ninety-seven thousand rupiah) in 142 villages from 13 sub-districts. Specifically, for the details of the Village fund, each village in Wajo District for the 2019 fiscal year is allocated evenly and fairly based on the Basic Allocation, which is the minimum allocation of Village fund that will be received by each village evenly whose amount is calculated based on a certain percentage of the Village Fund budget divided by the amount village nationally. Then affirmation allocations, namely allocations that are calculated by taking into account the status of underdeveloped villages and very disadvantaged villages, which have a high number of poor people. And the last one is Formula Allocation, which is an allocation that is calculated by taking into account the total population of the village, poverty rate, area, and geographical difficulty level of each district/city.

In reality, there is a strong and developing impression among the community that the utilization of village fund sourced from the State Budget, which is billions of rupiah, has not provided significant benefits for poverty alleviation in Wajo District, especially in rural areas, where the poverty rate is still relatively high around $13 \%$, while the national average poverty rate is $9.41 \%$.

\section{METHODOLOGY}

The research used the case study method. Data collection techniques used were observation, interviews, and document review. Determination of research informants was carried out by purposive sampling consisting of local government officials, sub-districts, villages, academics, community leaders, members of the poor community, and non-governmental organizations that observe poverty. The research data were analyzed in a qualitative descriptive manner and supported by quantitative analysis.

\section{RESULT}

The results showed that village funds were funds sourced from the State Budget allocated to villages in Wajo District, which are transferred through the regional budget of Wajo District. The village fund can be used to finance governance, implementation of village development, community development, and empowerment of village communities. Based on the regulation of the Wajo Regent No.6 of 2019 concerning technical instructions and procedures for the distribution and determination of details of village fund in Wajo District for 2019, it is allocated equally and fairly based on (a) Basic allocation, i.e., each village is calculated based on the District's basic allocation, then divided by the number of villages in accordance with the provisions of the statutory regulations regarding the details of the 2019 State Budget; (b) Affirmation allocation, namely every village in Wajo District, especially underdeveloped villages that have a high number of poor people, the amount of affirmation allocation given to each village is calculated based on the provisions in the statutory regulations regarding the procedures for allocating village fund; (c) Formula allocation, namely the allocation calculated by taking into account the population, poverty rate, area and geographic difficulty index of each village. The amount of affirmation allocation given to each village is calculated based on the provisions in the laws and regulations regarding the procedures for allocating village fund; (c) Formula allocation, namely the allocation calculated by taking into account the population, poverty rate, area, and geographic difficulty index of each village.

There are 142 villages in 14 Sub-districts in Wajo District; details of village fund were determined according to Wajo Regent Regulation No. 6 of 2019 based on three village fund allocations, with a total village fund of Rp. 119,030,097,000 (One Hundred and Nineteen Billion Thirty Million and Ninety-Seven Rupiah). From the village fund received by each village in Wajo District, the distribution of village fund is based on the Wajo Regent Regulation No.7 of 2019 concerning the procedures for distributing and determining the details of village fund for each village in Wajo District for the 2019 fiscal year which is the focus of this research, that the distribution Village fund isis carried out through book-entry from the regional general cash account to the village general cash account. Book-entry form the regional general cash account to the village general cash account is done seven working days after the village fund are received from the regional general cash account, and after the distribution requirements have been met, the distribution of village fund is carried out in stages based on the provisions stipulated in the Wajo Regent Regulation, namely: (a) Phase I at the earliest in January 2019 and no later than the third week of June 2019 at 20\%; (b) Phase II at the earliest March 2019 and no later than the fourth week of June 2019 at 40\%; (c) Phase III at the earliest in June 2019 and no later than the fourth week of October 2019 at $40 \%$. 
From the results of the research based on a study of the documents for the distribution of village fund sourced from the state budget, from the regional general treasury to the village general treasury account after the Regent received the required documents, namely in the first stage in the form of a village regulation regarding the village head's income and expenditure budget. The second stage is a report on the realization of the absorption and the achievement of the output of the village fund for the previous budget year; the third stage is a report on the realization of the absorption and the achievement of the output of the second stage of village fund. Apart from the required documents, the village head, as the power of village financial management, submits other documents in accordance with the village fund distribution mechanism. And reports the absorption of village fund output phase two shows the average for the least of $75 \%$ of the average output by showing at least $50 \%$.

\section{Village Fund Utilization}

In article 1, paragraph 2 of the Government Regulation of the Republic of Indonesia number 60 of 2014, it is emphasized that village fund are funds that come from the State Budget allocated to villages and are transferred through the district regional income budget, used and utilized to finance government administration, implementation of development., community development and community empowerment.

The results showed that village fund comes from the State Budget and are transferred to the Wajo District Regional Budget and forwarded to the village general treasury to be utilized, and prioritized to finance village development activities and empowerment of village communities aimed at improving the welfare of rural communities, improving the quality of human life and reducing poverty. Village funds in Wajo District from 2015 to 2020 continues to increase every year. In 2015 the amount of village fund received in Wajo District was Rp. 82,146,141,000 (eighty-two billion one hundred forty-six million and one hundred forty-one rupiah) increased in 2016, amounting to Rp.87,194,141 (Eighty-seven billion hundred and ninety-four million hundred and forty-one thousand rupiah). In 2017, it was increased to Rp. 104,219,771.000 (one hundred four billion two hundred nineteenth million seven hundred seventy-one thousand rupiah). In 2018, it was increased again to Rp. 111,165,441,000 (One hundred eleven billion, one hundred sixty-five million four hundred forty-one thousand rupiahs). In 2019, it was increased to Rp. 119,030,097,000 (one hundred and nineteenth billion thirty million and ninety-seven thousand Rupiahs). And in 2020, it continued to increase to Rp. 121,979,533,000 (One hundred twenty-one billion and nine hundred seventy-nine million and five hundred thirty-three thousand rupiahs), as shown in Figure 1.

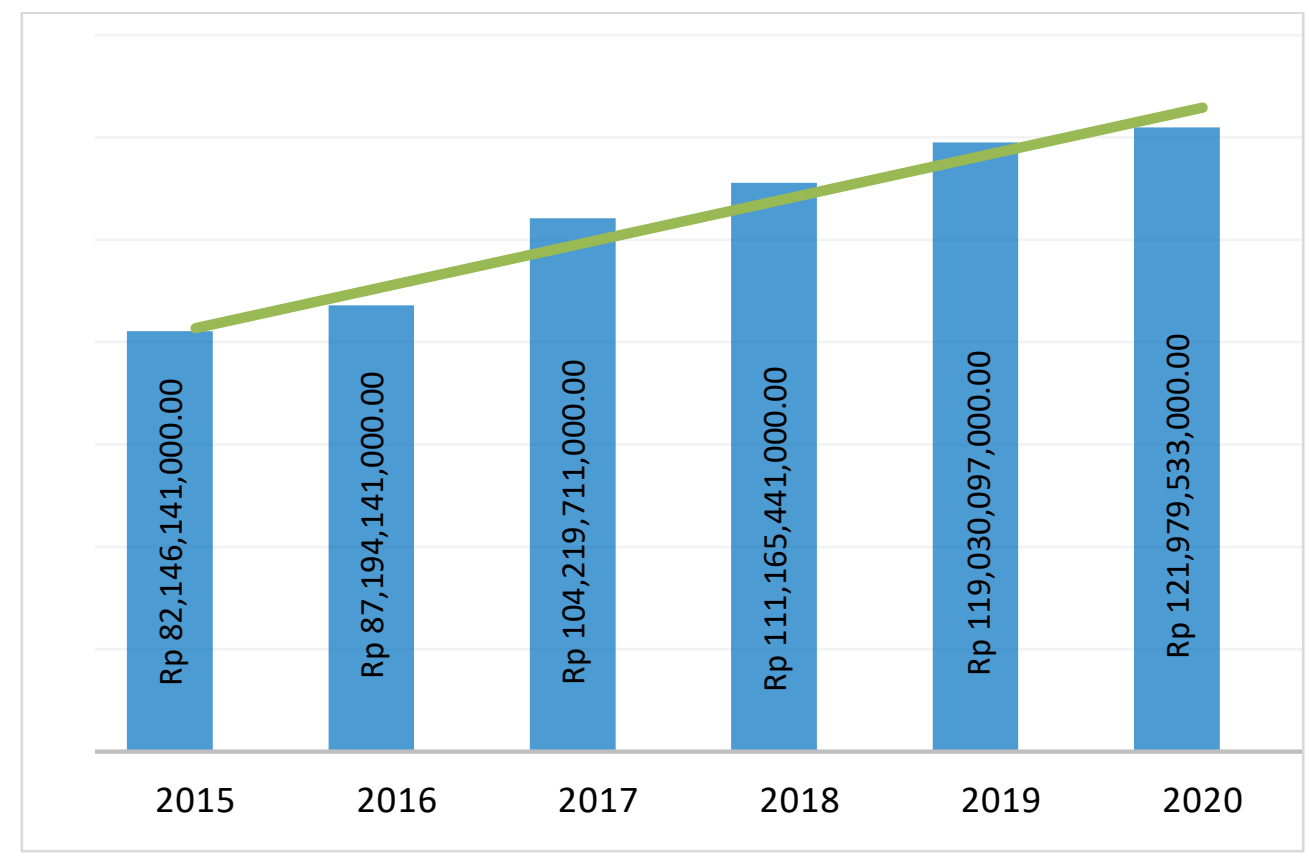

Fig 1. The trend of Village Fund, Wajo District

Village fund allocated to 142 villages and 13 Sub-districts in Wajo District from 2015 to 2020 have increased from year to year, where the utilization village fund are still prioritized for village infrastructure development. In the sense that village infrastructure development still dominates the use of village fund, and the results of observations in the field and 
supported by data and information, most of the village fund are used for village infrastructure development, data for 2019 which is the focus of research provides an overview of the use of village fund in Wajo District.

The use and utilization of village funds in poverty alleviation are still prioritized in the development of village infrastructure such as roads, bridges, drainage, repair of irrigation, repair of village offices, and so on. An average of 95.28\% of each village in Wajo District that receives village fund uses and utilizes village fund for village infrastructure development, and only an average of $4.72 \%$ for village community empowerment, it means that village fund is used more for village physical development activities compared to utilization of village fund for activities in the development and empowerment of village communities in poverty alleviation of rural communities. Village infrastructure development activities financed from village fund in Wajo District are as follows: (a) Procurement, development, construction, and maintenance of residential environment facilities and infrastructure, including: (1) Construction or improvement of residential houses; and (2) Other residential facilities and infrastructure in accordance with the needs of village conditions in Wajo District which are decided through village deliberations. (b) Procurement, development, and maintenance of transportation facilities and infrastructure include (1) Village settlement roads; (2) Village's Axis Roads; (3) Village roads between settlements to agricultural areas; (4) Village bridges; and (5) The culverts. (c) Procurement, construction, development, and maintenance of health facilities and infrastructure, among others: (1) Clean water at village scale; (2) Village environmental sanitation; (3) Toilet; and (4) Medical centers and posyandu (Integrated Healthcare Center). (d) Procurement, construction, development, and maintenance of agricultural production facilities and infrastructure for food security and productive scale agricultural businesses that are focused on the policy of one village one superior product, including: (1) Village irrigation; (2) Agricultural land printing; as well as (3) Others production facilities and infrastructure according to the analysis of the needs and conditions of the village in Wajo District which were decided in village deliberations. (e) Procurement, construction, and maintenance of facilities and infrastructure for dealing with natural disasters and/or extraordinary events, among others: (1) Cleaning of housing areas affected by natural disasters such as floodwaters, and (2) Rehabilitation and reconstruction of housing environments affected by natural disasters.

The use and utilization of the village fund to date is that most of the village funds are utilized to finance village infrastructure development. Based on the results of field research through direct observation, it showed that there are still many villages in Wajo District whose infrastructure is not built. According to an informant from a member of the Village Consultative Body, he stated that a lot of village fund in Wajo District are still used for village infrastructures development such as village road construction, village road repairs, village's office repairs, and those that are still related to other physical developments because the development of the village infrastructure is the easiest and the results are quickly visible, although the use of village fund for village community empowerment activities is also provided with funds, but relatively still small in poverty reduction (Interview on 14 June 2020).

The results showed that the amount of village funds used and utilized for fostering and empowering village communities in the context of poverty reduction and alleviation in 142 villages in Wajo District is relatively small, only $4.72 \%$ of the total amount of village fund for 2019, which amounts to Rp. 119,030,097,000 (one hundred and nineteen billion and thirty million and ninety-seven thousand rupiah).

Law No. 6 of 2014 concerning Village explains that the empowerment of village communities is a manifestation of village independence in carrying out joint movements as a unit of village governance. Village community organizations, customary institutions, as well as economic and environmental order units empowerment of rural communities are carried out through efforts to develop community independence and welfare by increasing Knowledge, attitudes, skills, behaviors, poverty, awareness, and utilizing resources through the establishment of policies, programs, activities and assistance that is in accordance with the essence of the problem and the priority needs of the village community.

The results of the research showed that the amount of village funds used for empowering village communities in the context of poverty reduction and alleviation in 142 villages in Wajo District is relatively very small, only $4.72 \%$ of the total village fund for 2019, which amounted to Rp. 119,030,097,000 (one hundred and nineteen billion and thirty million and ninety-seven thousand rupiah). Village community empowerment activities that can be funded from village funds include the following: (1) Management of community service activities, including (a) Provision of clean water; (b) Environmental health services; and (c) Management of village medical centers. (2) Management of educational and cultural service activities, among others: (a) Early Childhood Education (PAUD) teacher incentive assistance; and (b) Teacher incentive assistance on religious learning center. (3) Establishment and development of Village-Owned Enterprises and/or Joint Village-Owned Enterprises, among other things: (a,) Establishment of Village-Owned Enterprises and/or Joint Village-Owned Enterprises; and (b) Strengthening the capital of Village-Owned Enterprises and/or Joint Village-Owned Enterprises.

The use and utilization of village fund for the empowerment of village communities in the context of poverty alleviation in rural areas of Wajo District illustrate that village fund prepared by the village government in the assessment 
of many informants to be relatively few to be used or utilized in uplifting the dignity of the poor in the sense of village fund is utilized to relieve the burden to the community members who reside in 142 villages in Wajo District.

According to an informant from the local government apparatus who works at the Village Community Empowerment Service Agency, stated that the village fund provided by the central government sourced from the State Budget cannot be denied that are still prioritized for village physical development compared to village fund for community empowerment activities with various activities through efforts to develop self-reliance with the welfare of the village community, including village fund for training activities to improve abilities, skills for members of the village community both among farmers, breeders, laborer, and young people who are still unemployed, and including members of the community who are still classified as poor to have skills that will be used in work which in turn can increase their income, so that they can meet other basic needs.

This is in line with what was stated by local government officials who work at the Regional Secretariat Office, arguing that the village fund received by the Wajo District Regional Government originating from the State Budget from 2015 to 2019 is still prioritized for the use of village physical development. It is acknowledged that the village fund budget for the empowerment of village communities is still very low provided in the village budget. The village fund for activities that the report receives to submit to the local government reports on the use of village fund for community empowerment expenditures that are used for the following activities: (a) Capacity building of village government officials; (b) Training/technical guidance/ introduction to appropriate technology for fisheries land/fishermen; (c) Training/ technical guidance/introduction to appropriate technology for agriculture and animal husbandry; (d) Training/counseling for women's empowerment; (e) Child protection training/counseling; (f) Training and strengthening of persons with disabilities; (g) Provision of appropriate technology for non-agricultural rural economic development; (h) Training on management of Village-Owned Enterprises (Training conducted by villages; and (i) Establishment/facilitation/training/assistance of productive economic business groups (craftsmen, traders, and home industries).

This training activity aims to increase knowledge, skills, and change attitudes so that they can help members of the village community in doing their work as farmers, cultivators, craftsmen, traders, home industries to increase their income, which in turn can improve the welfare of rural communities. Through these various training that also involves community members who are in the poor category to improve their knowledge and skills, so they can work and try to change their fate, at least helping to increase their income in order to meet basic needs (Interview on 20 June 2020).

According to one of the informants of the members of the non-governmental community of rural observers and the problem of poverty, which suggests that rural problems in Wajo District gradually become more complex. Poverty, dependency, lag, low productivity, low quality of human resources, and unforeseen unemployment have become a typical problem of poverty in rural areas that are not simple. Because it can include poor nutrition, habitable homes that are many found in the countryside, lack of access to health services, education, clean water, and environmental sanitation. The complexity of rural problems requires the good attention of district governments, sub-districts, village governments, and rural institutions to set up budgets for inclusion in village budgets to be used in addressing rural issues. Further expressed from the review of the implementation of fund utilization hundreds of millions of rupiah originating from the central government, a specifically very minimal village that seriously worked on the poverty reduction program, almost $90 \%$ of the village in Wajo District is interested in financing the visible and low development program in the implementation of the physical development program which is even referred to as a solution in poverty reduction. Ideally, the village budgets as the currency of the budget to finance the operation of village governance and village community empowerment are encouraged to be decisive in the program of poverty reduction and alleviation in the village will be maximal if part of the priority program in the village medium-term development plan (RPJMDes). So, there is an obligation that the village budgets support the poverty alleviation activities in the allocation of adequate budgets, a priority program in the implementation of village budgets every year. From our observation, it tends to ignore the community empowerment in which there is an initiation of poverty reduction and alleviation in rural areas. Also, the routine activity of the village development forum (Musrembangdes) tends to be dominant by the interests of village elites who lack a view of poverty reduction. The results can be predicted that the increase in the amount of village fund each year provided by the central government, and the increase in the volume of village budgets do not contribute significantly to poverty alleviation in Wajo District (Interview on 23 June 2020).

Factors Affecting Village Fund Utilization in Poverty Reduction

Village fund originating from the State Budget given to 142 villages in Wajo District are used and utilized to finance village development activities, government activities, community development, and empowerment, in the context of poverty reduction and alleviation, faced with regulatory conflicts between the Regulation of Ministry of Villages, Development of Disadvantaged Regions, and Transmigration of the Republic of Indonesia and the Ministry of Home Affairs of the Republic of Indonesia, where the village has two regulators. The two ministries have issued financial regulations regarding the use and utilization of the village fund. According to the regulation of the Minister of Villages, Development of Disadvantaged Regions, and Transmigration of the Republic of Indonesia No. 5 of 2015 from Article 
5, the village fund is prioritized only for the aspects of village development. According to Presidential Regulation No. 12 of 2015 concerning the task of the Ministry of the Villages is only focused on the aspect of village development, the priority of use and utilization of village fund to provide for village government operational financing, and it means to eliminate the Ministry of Home Affairs duty to strengthen the village government according to Presidential Regulation No. 11 of 2015. In-Law No. 6, the year 2014, concerning the villages, where the village fund sourced from the State Budget State, it is clearly stated that the function of the village fund is to finance the activities of government, development, coaching, and community empowerment.

The results of the study indicated that regulatory conflicts are one of the factors that can affect the use and utilization of village funds in poverty alleviation in rural areas of Wajo District. At the beginning of the existence of the village fund sourced from the State Budget, it was clearly stated that the function of the village fund was to finance government activities, development, fostering, and community empowerment. With these two rules, the village government faced difficulties in utilizing village funds, especially in making village regulations about the village budget. In the end, the village government followed more rules from the regulations issued by the Ministry of Villages, Development of Disadvantaged Regions, and Transmigration, which village fund was mostly used or prioritized for village physical development. At the same time, the budget for poverty reduction and alleviation through village community empowerment programs has not been a priority scale. It is seen until 2019; the village fund is prioritized to the development of village infrastructures such as roads, bridges, drainage, village office construction, and irrigation. If compared to the village fund for poverty reduction and alleviation, it is relatively very low through a community empowerment program that is in the form of a cash-intensive program.

\section{Supervision and Evaluation}

Supervision of the use of village funds from 142 villages in Wajo District is carried out in the context of monitoring the implementation of village governance, including village finances for the local village scale. Law Number 6 of 2014 concerning villages confirms that one of the obligations of the Village Consultative Body is to supervise and ask for information on the implementation of the village government to the village government includes the flow of use and utilization of village funds sourced from the State Budget. Village deliberations held by Village Consultative Body become the official forum for conducting village-based supervision. The annual supervision policy starting in 2016 has mandated district inspectorates to supervise the use and utilization of village funds.

According to an informant from the district inspectorate, he stated that the use and utilization of village fund for poverty alleviation in Wajo District require close supervision not only from the regional and sub-districts governments but also from the community because village fund comes from the State Budget are large enough to potentially be abused by certain parties. From the results of the research also can be seen that the use and utilization of village fund to overcome the problem of poverty in rural areas requires a strong supervisory institution in which it consists of government officials, sub-districts, members of Village Consultative Bodies, village escorts to supervise the use of village fund sourced from the State Budget. Because of various information from newspapers and social media state that the village fund is prone to be abused.

\section{Village Elites Commitment to the Village Fund Effectiveness}

In the reality of managing village funds in 142 villages in Wajo District, which is regulated in Minister of Home Affairs Regulation No. 113 of 2015, there are several dimensions of weakness that make the effectiveness of the use of village funds in poverty alleviation is not in line with expectations.

The research results showed that from the perspective of the mechanism for determining the priority for the use and utilization of village fund sourced from the State Budget following the development planning process and village budgets, the documents produced in the village planning process include Village Medium Term Development Plan (RPJMDesa), Village Government Work Plan (RKPDesa), and Village Budgets (APBDesa). However, the weaknesses in the use and utilization of village fund in poverty reduction are obtained from various information sourced from several informants, both among community leaders, village assistants, and district government officials who are considered as a representative, namely: (a) The existence of egocentric village head as the holder of financial management power village (PKPKD), where the village head plays more of a role and plays in planning, implementing and reporting village finances. Village heads are less able to streamline teamwork in formulating village government work plans and implementing village budgets. In the meaning of a lack of commitment by village elites, especially village heads who represent village governments in implementing the results of agreements on the use and utilization of village fund for poverty alleviation programs, between the village head, the Village Consultative Body, and elements of the community in accordance with the results of the village deliberations; and (b) There is a lack of understanding of the village elites, 
in this case, the village head regarding regulations and policies for managing village fund, there are still village governments who do not understand the substance and imperatives of legal rules and comprehensive guidelines in the management and utilization of village fund for poverty alleviation. Then the use and utilization of the village fund are limited only to the filing of village fund disbursement, formulation allocation of the usefulness of village fund, and administrative reporting. The village elites do not understand the substance of village funds as a medium strengthening the function and performance of village governance and a series of community empowerment programs to reduce the poverty rate in rural areas, as well as improve the welfare of villagers in Wajo District.

\section{CONCLUSION}

It can be concluded that (1) Village funds in Wajo District from 2015 to 2020 was given to 142 villages in 13 Subdistricts. The mechanism for distributing and using village fund is in accordance with the Wajo Regent Regulation No. 6 of 2019 concerning technical instructions for the distribution and determination of details of village fund to be allocated evenly based on (a) Basic Allocation, i.e., each village is regulated based on the allocation according to the provisions of the statutory regulations applies; (b) Affirmation Allocation, i.e., each village in Wajo District is given to underdeveloped villages that have a number of poor people; and (c) Formula Allocation which is calculated by taking into account the number of villagers, the poverty rate, the area, and the geographic difficulty index of each village; (2) The utilization of village fund is more focused on village development activities (village physical infrastructure), 95.28\% of the total village fund, compared to the use of village fund in fostering and empowering rural communities (4.27\%) in reducing poverty. The use of village fund sourced from the State Budget has not significantly contributed to reducing the poverty rate in 142 villages in Wajo District, this showed that the poverty rate in each village is still stagnant and even increasing; (3) The factors that influence the use and utilization of village fund in poverty alleviation are: (a) Regulatory conflicts between the two ministries that regulate rural areas, namely the regulations of the the Ministry of Villages, Development of Disadvantaged Regions, and Transmigration and the Ministry of Home Affairs, so that village fund are sourced from the State Budget have not been focused on poverty alleviation programs, but are more focused on village infrastructure development programs; (b) Weak supervision of the use of village fund from the central, district and sub-districts governments has resulted in the use of village fund to help the poor have not been on target; and (c) Lack of commitment of village elites both in the village government and the members of the Village Consultative Body to create a village fund program to assist the poor in rural areas.

\section{References}

[1]. A S Kazi et al., Distributed engineering in construction: findings from the IMS GLOBEMEN project Itcon, vol. 6, pp. 129-148, 2001.

[2]. S. K. Manna and K. S. Chaudhuri, "An EOQ model with ramp type demand rate time dependent deterioration rate unit production cost and shortages", European Journal of Operational Research, vol. 171, pp. 557-566, 2006.

[3]. S Panda, S Senapati and M. Basu, "Optimal replenishment policy for perishable seasonal products in a season with ramp-type time dependent demand[J]", Computers and Industrial Engineering, vol. 54, pp. 301-314, 2008.

[4]. S D Peter, H J Robert and P C. Lin, A note on the inventory models for deteriortating items with ramp type demand rate EuropeanJournal of Operational Research, vol. 178, pp. 112-120, 2007.

[5]. K Skouri, I Konstantaras and S. Papachristos, "Inventory models with ramp type demand rate partial backlogging and Weibull deteriorationrate European", Journal of Operational Research, vol. 192, pp. 79-92, 2008.

[6]. Love, Peter E.D.; Edum-Fotwe, Francis; Irani, Zahir "Management of knowledge in project environments" [J] International Journal of Project Management 21 (2003) pp.155-156

[7]. Nikos Karacapilidis, Emmanuel Adamides and Christina Evangelou,"A computerized knowledge management system for the manufacturing strategy process" [J] Computers in Industry ,February 2006, pp.178-188 